\title{
Educational Institution on Responding Disasters in Palu of Indonesia
}

\author{
Ismail Suardi Wekke \\ State Islamic Institute (STAIN) Sorong, Indonesia \\ Email: ismail@stain-sorong.ac.id \\ Rajindra Rajindra \\ University of Muhammadiyah Palu, Indonesia \\ Email: rajindra@ unismuhpalu.ac.id \\ Dinil Pushpalal \\ Tohoku University, Japan \\ Email: dinil.pushpalal.b4@tohoku.ac.jp \\ Muhammad Ahsan Samad \\ University of Tadulako Palu, Indonesia \\ Email: ahsansamad@untad.ac.id \\ Ahmad Yani \\ University of Muhammadiyah Palu, Indonesia \\ Email: ahmadyani@unismuhpalu.ac.id \\ Rofiqul Umam \\ Department of Applied Chemistry for Environment, Kwansei Gakuin University, Japan \\ Email: egk71822@kwansei.ac.jp \\ Paper Presented \\ International Conference on Islam and Higher Education
}

Padang, Indonesia 19-120 February 2019

\begin{abstract}
The earthquakes that occur in the Indonesia are caused by several primary factors such as the tectonic plate shifts which lead to the increased activity of earthquakes and volcanoes. Moreover, the geological condition and the rock structure of swathes of Indonesia constitute the secondary factor that contributes to the danger of the disaster in Indonesia. Various disasters having occurred in the last 2 years are summarized in this article. This study was aimed to provide information concerning the history as well as attempts to cope with disasters and impacts on society following the disasters in Indonesia. The qualitative case study methodology was selected along with sources derived from various community groups as well as governmental agencies such as BNPB (The National Agency for Disaster Countermeasure) and BMKG
\end{abstract}


(Meteorological, Climatological, and Geophysical Agency) that serve as a reference in this study. The results of the study delineated that the community's response to the natural disasters led to increased security mitigation efforts made by the community and the government. In addition, it affected social relationship between communities in a positive manner evidenced by participation in helping with the post-disaster recovery.

Keywords: Palu City, Earthquake, Disasters, Indonesia

\section{Introduction}

In the last decade, throughout the world, particularly in the well-known region as the ring of fire, earthquakes frequently occur. This earthquake is triggered off by the dynamic movement of the tectonic plates on the lithosphere. Earthquake often hits countries along the Ring of Fire (ROF) (Holloway, 1883) such as New Zealand, Eastern Australia, Japan, the Philippines, the west coast of North America, the west coast of South America, and Indonesia. The magnitude of the earthquake varies, ranging from minor magnitude <4SR, moderate magnitude 4-6, to great magnitude> 6SR(Putra, Kiyono, Ono, \& Parajuli, 2012).

The quakes occurred in Indonesia in the span of two years namely in 2017 and 2018. The quakes are associated with the fact that Indonesia is an archipelago including many volcanic mountains, faults, and meeting points between the Australian plate and the Asian plate along the southern coastal region of Indonesia to the western coastal region of Indonesia (Mardiatno, Malawani, Annisa, \& Wacano, 2017). The earthquakes are not only caused by the tectonic plate shifts but also volcanic activity in Indonesia such as the ones hitting the island of Lombok that claimed 555 lives and sent 390,529 people fleeing for a refuge, and another one rocking the city of Palu in central Sulawesi which took death tolls of 2,113 people following tsunami (Nugroho, 2018), and the last one striking the southwestern region of Indonesia, LampungBanten which killed 437 people in Sunda Strait tsunami and left 14,059 people injured. These earthquakes are caused by various main factors. The earthquakes hammering the island of Lombok are brought on by the Australian tectonic plates moving northwest - north (Lewerissa, Sismanto, Setiawan, \& Pramumijoyo, 2017). The movement of the Australian tectonic plates reaches approximately $60 \mathrm{~mm} /$ year (Valkaniotis, Ganas, Tsironi, \& Barberopoulou, 2018). Meanwhile, the quakes that rattled the city of Palu in Central Sulawesi is caused by the built-up grinding pressure of the Australian plates and Phillipine plate in addition to the vulnerability of the city of Palu to tremors triggered by the slip in the fault and liquefaction in the area (Gaffar et al., 2018).

The predominant cause of the earthquake hitting the southwestern part of Indonesia or Lampung-Banten, was volcanic activity (Putra et al., 2012). Volcanic Mountain, which is Anak Krakatoa is formed by the large eruption of Mount Krakatau in 1883. The ceaseless activity of Gunung Anak Krakatau continues to increase because the Australian plate moves under the earth through subduction along the southern coast of Java and Indonesian Sumatra. (Holloway, 1883). 


\section{Literature Review}

A series of earthquakes occurred in Indonesia starting with Lombok, Palu, and Banten Lampung. Natural events ensuing in the earthquake-prone areas, especially Indonesia (Figure 1) (Putra et al., 2012) result in people's learning how to survive in the Indonesian region. With disasters being increasingly a part of the life of the Indonesian, a need arises to commit to writing historical series of events worth remembering and evaluating instrumental in keeping the aftermath losses down in the event that an earthquake strikes in the future which serves as a record of life.

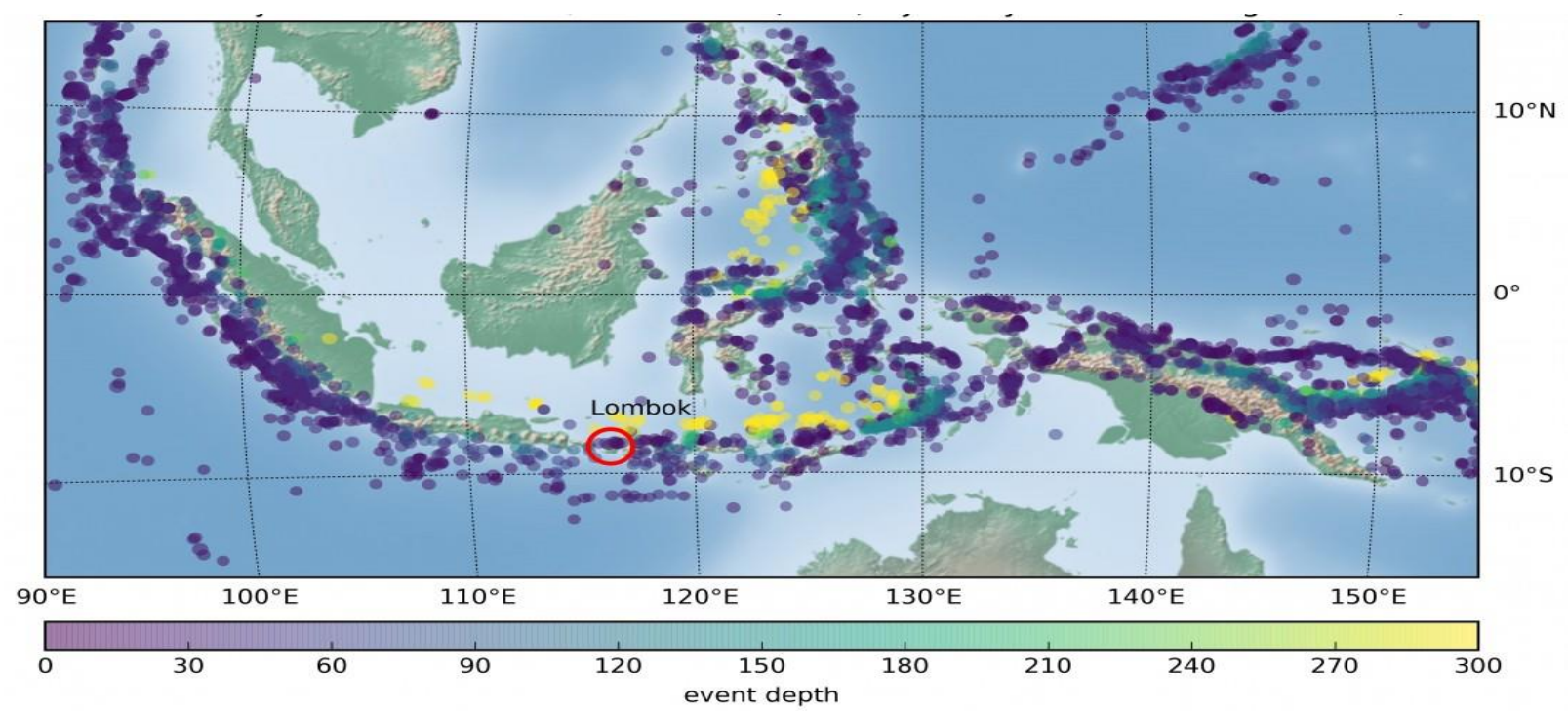

Figure 1. Seismicity map of Indonesia region (Source: (BMKG, 2018; USGS, 2016) period 2000-2018).

The National Disaster Management Agency (BNPB) has set a high risk tsunami in Indonesia to be included in the Indonesian Tsunami Master Plan in the 2012. Based on this document, Indonesia is divided into four high risk tsunami areas, namely megawrust Mentawai, Sunda Strait and south (Sismanto, 2015). a part of Java, Bali and Nusa Tenggara, as well as the Papuan region (Figure 2). 


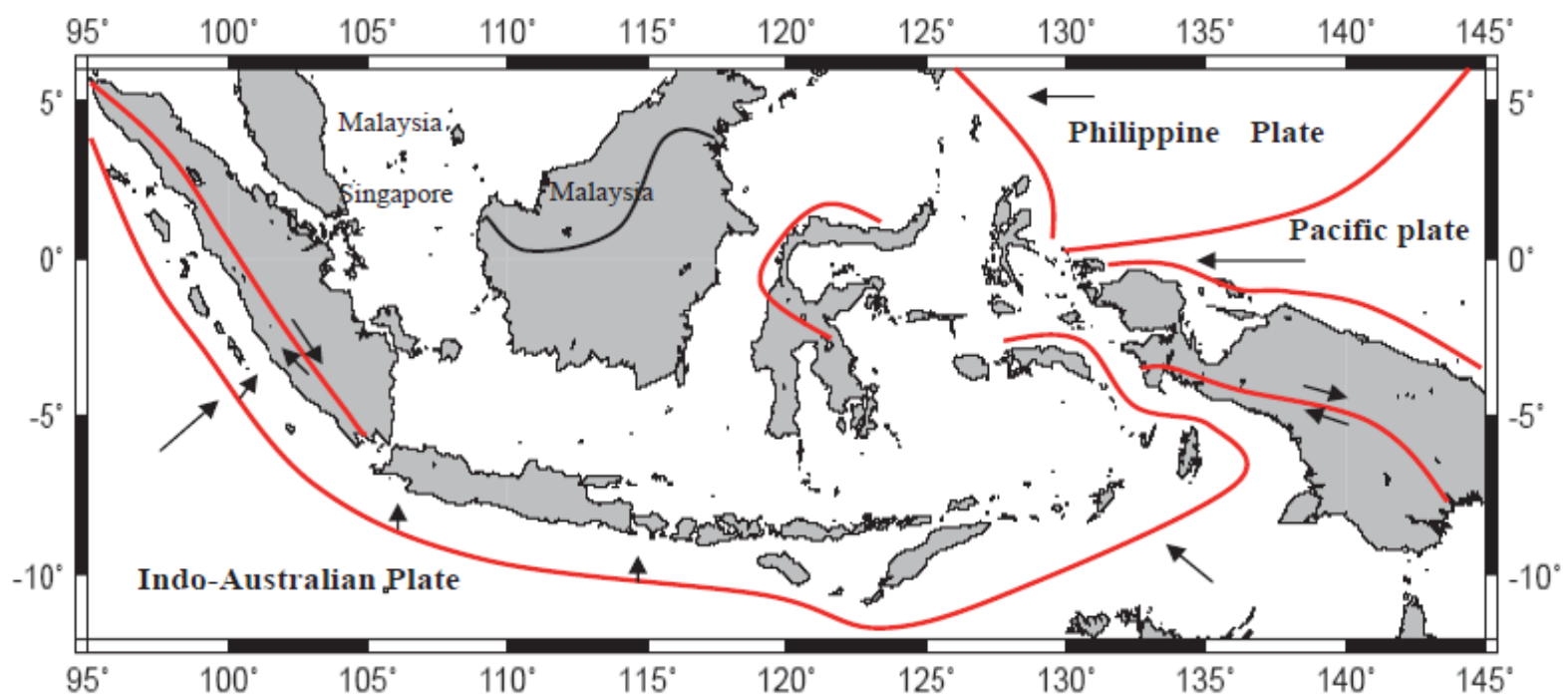

Figure 2. Potential Hazard of Tsunami Disaster in Indonesia (Pramono \& Harapan, 2018).

The observation conducted by BNPB over the region, many people are exposed to the danger of tsunami. More than 2.5 millions of people are vulnerable to occurences of tsunami (BNPB, 2014). The number of people exposed to tsunami can be seen in Table 1. According to (Nohara, 2011), people generally prefer to inhabit areas which potentially support their daily living (Nugroho, 2018). However, they ocassionally disregard the potential hazard since the choices are limited if they can choose where to live (Lewerissa et al., 2017). Under such circumstance, challenges and opportunities present themselves in terms of the tsunami risk management in Indonesia (Diambama, Anggraini, Nukman, \& Lühr, 2018). The first challenge is "how to minimize the tsunami risk in all areas? There are some obstacles to the tsunami risk management application in every area (Lin \& Henschke, 2018). The possible issue emerges from the lack of preparation or the mismanagement carried out in every area.

Table 1. Number of People Exposed in Priority Area of Tsunami Mitigation [Source: (BMKG, 2018;Pramono \& Harapan, 2018)].

\begin{tabular}{|c|c|c|c|}
\hline No & Priority Area & Province & Nr. of people exposed \\
\hline \multirow[t]{3}{*}{1} & Megathrust Mentawai & North Sumatera & 106,601 \\
\hline & & West Sumatera & 298,203 \\
\hline & & Bengkulu & 98,246 \\
\hline \multirow[t]{6}{*}{2} & Sunda Strait and Southern part & Lampung & 43,004 \\
\hline & of Java & Banten & 346,381 \\
\hline & & West Java & 123,095 \\
\hline & & Central Java & 943,497 \\
\hline & & Yogyakarta (DIY) & 92,342 \\
\hline & & East Java & 194,649 \\
\hline \multirow[t]{2}{*}{3} & Bali and Nusa Tenggara & Bali & 358,905 \\
\hline & & West Nusa Tenggara & 119.138 \\
\hline
\end{tabular}




\begin{tabular}{|c|c|c|c|}
\hline & & East Nusa Tenggara & 31.823 \\
\hline \multirow[t]{3}{*}{4} & Papua region & West Papua & 14.092 \\
\hline & & Papua & 20.998 \\
\hline & \multicolumn{2}{|c|}{ Total } & 2.790 .974 \\
\hline
\end{tabular}

Aside from earthquakes, the possible danger of a tsunami in eastern Indonesia such as in Maluku, the northern part of Papua and Sulawesi should be given due consideration (Pribadi, Afnimar, Puspito, \& Ibrahim, 2013). Based on the facts issued by BNPB, to conceive tsunami mitigation plans, the hazard information gleaned must include the consideration of the worst case scenario which is done so by estimating the maximum level of inundation generated by the tsunami modeling (National Agency for Disaster Management (BNPB), 2015). Concerning the evacuation route, a route with a high index of tsunami victims must be kept free from the evacuation before the tsunami reaches. This is also possibly carried out by using tall buildings that are located within the tsunami inundation area. On the other hand, coastal areas containing sandy and muddy materials tend to run a higher risk of tsunami. Different mitigation treatments must be administered to the two different regions, such as by planting mangroves to take the brunt of tsunami crashing in (Rashid, M; Vetha, Roy D; Chandrasekhar, 2010). It is also of importance to plan rural land use to minimize coastal hazards (eg tsunami impacts). This is a part of a mitigation strategy intended for the protection of coastal areas instrumental in the conservation of coastal resources and rescuing people living in that location (Nguyen, Griffin, Cipta, \& Cummins, 2015). In addition, the development of coastal forests and coastline belt is also crucial for tsunami mitigation. Such mitigating strategies are most effective and more economical compared to the construction of solid structures. However, the planting of mangroves takes a while (Boen, 2008).

In this study, the historical record of natural disasters has been made to learn how to come up with disaster mitigation measure in the future. It is also a necessity to take notes of the community activities and government responses (Kongko \& Hidayat, 2014). So that in the future, this research can serve as a reference in terms of the disaster mitigation and history not only in the region of Indonesia, but also an example to follow for other parts of the world. The study of tsunami mitigation plans in Indonesia is a topic of interest referring back to all the challenges previously mentioned.

\section{Method}

This qualitative research employed a type of a case study, literature studies, and the latest data derived from various social elements. This article illustrates the conditions of the affected areas, whatsoever information has been obtained from the government and social assistance from various elements of the community, and attempts made to interview the community in the wake of the disaster. In addition, data were collected by conducting interviews, focus group discussions (FGD) alongside with scientific findings considered to buttress the accuracy and systematicity of the research results. (Figure 3 ).. 


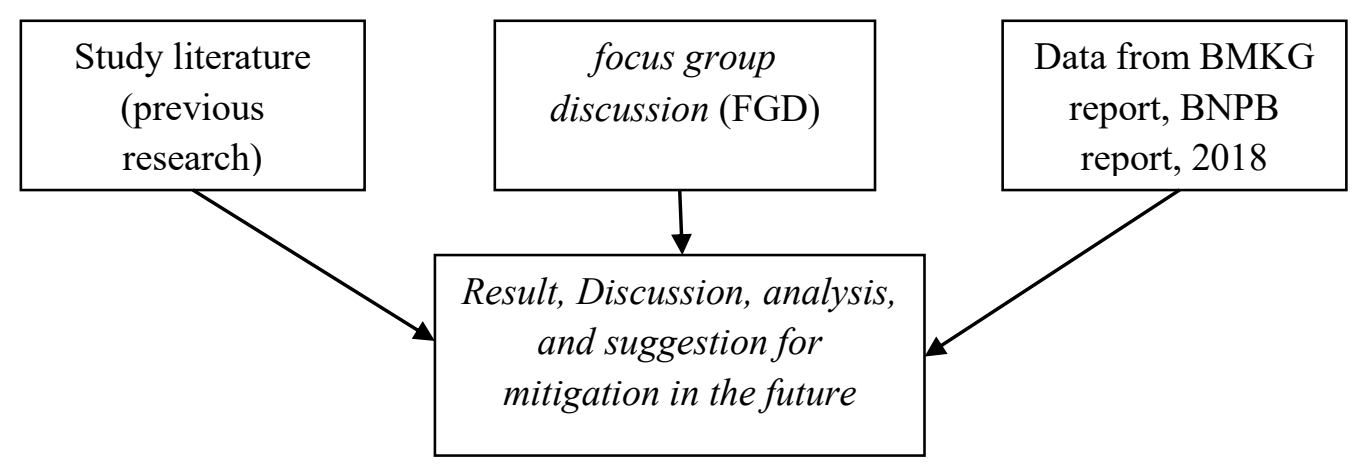

Figure 3. Method from various data collection techniques.

In addition, this article was also written to provide an overview of how to draw up a good disaster mitigation policy. This article conveys initial findings that present data from homogeneous sources. Alternative approaches selected are consistent with the characteristics of each region. The tsunami mitigation action plan is one of the management arrangement. This article is aimed to serve as a literature on which basis a National Action Plan for Disaster Risk Mitigation (RAN-PRB) for a period of 10 years is made. The framework used to conceive action plans in general is by taking coastal typology and settlement approach in the Indonesian region (Figure 2).

\section{Results}

The earthquake occurring on September 28, 2018 in Palis a phenomenon with a farreaching impact as it is followed by a surge of tsunami hitting with three waves. The people in Palu calls it a high-wave. Ensuing afterwards was liquefaction in the Balaroa Housing area, Jono Oge Village and Petobo Subdistrict. The community managed to get back to normal life four months after the disaster (Valkaniotis et al., 2018).

Data released by BMKG revealed that the earthquake would continue to strike as long as the geological conditions in the disaster-prone area were unstable. The BNPB also said that the number of victims would continue, and victims reported missings due to liquefaction that followed (Rusydi, Efendi, Sandra, \& Rahmawati, 2018). Secondly, this report rendered the community anxious and restless. Network communication was literally cut off raising a concern from the people outside of Palu, particularly those who have relatives remaining in Palu.

Meanwhile, the disaster was compounded even more by the airs of hoaxes circulating through the community concerning the failure of the mayor and deputy mayor to spring into action dealing with the disaster. In fact, at eight o'clock the two of them had stepped in to address the problem by dealing with the corpses at the scene. The community suspected that which is not confirmed that the three disasters are deemed as God's dealing or the so -called adzab as he found fault with human behaviors.

After the earthquake, tsunami and liquefaction occured, assemblages of people form for prayers which also included the beach which was the worst-hit location unfolding the damaged buildings reaching fifteen meters from the shoreline. Praying assembly was held regularly in 
several mosques. A few hours after the tsunami reports of people thieving goods went about. Perpetrators were at large in the night time and continued to do so until two days after. The word of the increased lootings arose from assumption that the government would pay for all the victims of the disaster. In fact, the news was the ministry's statement distorted.

This happened due to a shortage of law enforcement officers. While the police lost seven officers. The condition worsened as there was no one watching over and acting immediately on the theft and looting.

The people were longing for returning to trade that was initiated by peddlers. The peddlers even offered beverage on the beach where the tsunami hit a week after. Initially, they were afraid, dwelling on the need to make livelihood they had to do what they did.

Jusuf Kalla's visit was an encouragement. He came to present himself as the national disaster management coordinator and was able to find a solution to address the distribution of fuel oil. Each gas station could serve the community directly without queuing. Jusuf Kalla in his authority as the vice president and as Chairperson of the Indonesian Red Cross mobilized the community and local government to take immediate action.

To address the lecturing issues, through the Indonesian Rector's Forum, Tadulako University provides students who temporarily evacuate opportunities to sit in at the university in each province where they are. By simplifying the procedure and sufficient coordination, each student can attend classes with no concern for the payment obligations.

\section{Discussion}

Articles show that surviviors demonstrated resilience. Family is a major support system which helps survivors to recover immediately and resume their normal activities. A mother goes back to her selling activities on the beach after taking refuge with her children for a week in South Sulawesi. Similarly, a woman went on the quest for her mother in the affected area after receiving approval from her husband. She was waiting for 48 hours at the airport to get evacuated to Makassar. This shows that family support sustains them through post-disaster recovery.

The same is true with the family tie that binds the community in the four provinces in Sulawesi. They rendered financial help and sprang into a swift action to identify victims. As such, people working for the regional government, to elementary school students take the same action. The religious organization of Muhammadiyah worked together with the Muhammadiyah Disaster Management Center team did likewise. Furthermore, the University of Muhammadiyah Malang, the University of Muhammadiyah Purwokerto and the University of Muhammadiyah Palu altogether carried thematic lectures on disasters.

A disaster survivor who works as a lecturer took a shelter in hi uncle's house. His parents' house was destroyed. He stayed therein in the wake of the disaster. A week after the disaster occurred, some Palu residents fled to their safety by taking a refuge in other areas. The disaster wrecked the supporting facilities in the city such as electricity, clean water (PDAM), cellular networks and resulted in the scarcity of fuel at gas stations. Compared to the 2004 earthquake 
and tsunami in Aceh, public facilities were totally paralyzed. The government needs to heed that as a disaster strikes, the aid to be provided includes public facilities such as electricity. Electrical energy can be temporarily obtained from the diesel (Devi, 2007).

Furthermore, the urban community was consumed with severe trauma, because they were exposed to relentless aftershocks intensified by roaring sounds from the underground of the earth that many dreaded that the city of Palu would cave into the bottom of the sea. This chaos is worsened by several stories related by residents who said that the city used to be a land rising from the seabed through the earthquake and tsunami hundreds of years ago. And, they estimated that the land would slip back down to the sea. If we take into account the 2018 earthquake on the siiland of Lombok, the 2009 earthquake in West Sumatra, and 2004 Aceh earthquake - tsunami, the earthquake will continue (aftershocks) until the geological conditions are relatively stable (Commission, 2018). In this regard, the psychology or traumatic scale of the community will increase. Therefore, to overcome this, the government and the community could help out by keeping themselves calm through reciting prayers, entertaining children, and also providing updated information pertaining to seismic activity to the affected community (National Agency for Disaster Management (BNPB), 2015).

Some victims of the disaster interviewed by the author H. Bada, a man who is turning 70s this year. He left South Sulawesi for Palu in 1980s and started his culinary business until this day. he did not want to leave the city of Palu although many relatives from South Sulawesi came to Palu to fetch him. He holds fast to his principle that the accident and death had been destined by God, and that God had predetermined whatever befell him and his family long before a man was born to earth. Hence, he resolved to stay in with his extended family ( 7 children, 4 sons-inlaw, 8 grandson) by pitching a tent in front of his housestore and choosing not to join other refugees, even though he, his children and in-laws have all the facilities such as cars to evacuate to South Sulawesi.

The same is true with $\mathrm{Hj}$ Noni, a fruitmonger at the Inpres Manonda market in Palu. Being interviewed by the author, the mother of 5 children said that her family ran short of foods three days after the disaster. Her husband and childred had to travel several kilometers to look for help from relatives in the city. Things were very dreadful, but this 50-year-old woman stayed in with her family not wanting to go back to her hometown in South Sulawesi to relocate with her extended family. She pitched a tent in front of a kiosk where her place of business was, like the H. Bada, Hj Noni also did not want to leave his house for a refuge and chose to stay in with his family and fellow traders.

Both H.Bada and $\mathrm{Hj}$ Noni said that, some of traders from Bugis \& Makassar at the market in Palu's Inpres Manonda, chose to remain in front of their shop a few weeks after. Those who finally chose to take refuge in their native village in South Sulawesi were prompted by the situation such as the seriously injured family members, seniors, pregnant women and some toddlers while the rest remained to stick it out and help each other.

One of Bada's son-in-law said that after the disaster, fellow Bugis \& Makassar traders who chose to stay coordinated mutual help. For example, those selling rice donated some rice to 
the family of fruitmongers. Those selling vegetables set up public kitchens and cooked whatever was left over from their stocks, bakers and any old seller shared items in their possesion.

What happened to Amrullah, a young man in his 30s was different. He had a motor workshop in one corner of the city of Palu, a week after the disaster he chose to keep his business going in the city of Makassar, along with his family. However, two weeks later he chose to return to Palu City as he was worried about his workshop in the midst of the rampant looting of shops and supermarkets because he had many costly equipments which are easily sold. So he chose to go home and re-open his workshop a month after. The city was quiet as it was deserted by residents and only volunteers on guard were seen with the intermittent aftershocks.

The results of the FGD above reveal that when a disaster occurs, not everyone will flee the affected area as some choose to remain. They have different attitude toward the occurrence of disaster. Some people want to remain in the affected areas because they want to help other victims (Imamura et al., 2012).

A victim said that on the first day he opened his workshop, dozens of people came flocking into his workshop to get their vehicles repaired. Even some residents came to change their motorcycle tires with new tires. He remarked that on the first day he earned more than a million rupiahs which is fantastic amount as far as the size of his workshop is concerned.

The looting spread out to several locations especially places considered to have valuable merchandises. One of the warehouses located north of the city of Palu was ransacked. The author saw with his own eyes people tore down doors of the warehouse and snatched whatever they could lay their hands on. Even worse, in the center of the warehouse were dozens of pickup trucks parked to deliberately transport the goods they looted, said one resident to the writer.

The victims who witnessed incident firsthand stated that the looters came in from outside the city and did not experience direct impact of the disaster. He said that the residents of Palu were still traumatized by what happened that they were afraid to come into the building, especially until a week after. Meanwhile, others were still busy looking for lost family members that they could no longer think about searching for nor looting goods elsewhere. When compared to the disasters that occurred in Lombok in 2018, in West Sumatra in 2009, and in Aceh in 2004, community take different action in the wake of the disaster. The level of panic is heavily influential as the medical research states that the level of panic will occur when human beings cannot think well due to high distress experienced and intensified by the external factor such as hoax that the government allows public looting on shops or stalls for survival (AHA Center, 2018).

The public was apprehensive about the circulating news or information in the community about the occurrence of larger aftershocks than the ones happened on September 28, 2018 such as information given out by Mr. Rapiuddin that some people were prepared to leave the city to areas considered safer or distant from the disaster. Some people left for the southern Sulawesi region, some for Java. Only few of them chose to go to Central Sulawesi.

The earthquake, tsunami and liquefaction in Palu, Donggala and Sigi were traumatizing Burhanuddin, Farid and Ikhsan took a flight to Makassar when the plane landed they shouted 
frantically that earthquake wa hitting they were unaware that they were inside this plane. They slept through the flight before the plane landed. They thought there was another earthquake. Jamli's brother in the sub-district of Tondo experienced a panic attack when the gust blew a beam over that with a start he jumped on his motorbike to charge up the hill. He came to his senses when his wife shouted that it was not an earthquake.

In the same manner, people who walked along the shore were ill at ease when the tide was rising he thought there would be another tsunami striking again because he did not know that in the afternoon the sea rises up to a few meters over the road. Salmiati's mother was apprehensive everytime she passed the road on the edge of the beach thinking earthquakes, tsunamis and liquefaction could occur at any time because she heard about $25 \%$ of the fault had not come back into its place that disaster three times larger than the one occuring on September 28, 2018 ago was imminent. She thought it was better to stay away than to get close to places that could be hit by an earthquake or tsunami. Like the tsunami that occurred in Aceh in 2004, a series of earthquakes continue to occur until the soil or geological conditions are truly stable. However, this aftershock is not greater than the main earthquake that triggers a tsunami wave (Ramalanjaona, 2011).

Mr. Daeng believed on all the information he heard that he made the decision to move to South Sulawesi by selling all of his possesions including his kiosk at unreasonable prices as long as he got all sold he is severely traumatized by the earthquake which caused a cabine to be toppld and fall on him. Hearing the possible aftershocks, he resolved to go to a safer place because he thought to himself that possessions could be earned but soul could not. Community needs to be socialized on how to mitigate disaster by being mindful of their surroundings and whatever is available around their place of residence. Because objects such as cabinets, trees, which stand upright can fall on them as well as save them (Kathiresan \& Rajendran, 2005).

The Nusi family, Saharuddin and the Hasman family through the head of the neighborhood unit, Mr. Irwan explained to the writer that they chose to sleep outside of his house rather than inside the house because their mind was constantly on the possibility of greater earthquake striking than previous earthquakes. They also assumed that while sleeping outside they were expecting some help from the government such as food and drinks offered even though it had been informed that the aid was temporary and makeshift shelter provided they chose to sleep outside together with his family even though it was worse off to sleep outside. It is known that when earthquakes struck Padang, Jogja, Aceh, and Lombok, the community was advised to get outside to the open area lest aftershocks followed This is an effort to prevent more casualties. However, we also need to heed that liquefaction- prone areas shake and cause the ground to crack up and engulf things. Thus, evacuation efforts must also be furnished by information on areas that are safe from liquefaction (Yanagisawa, Koshimura, Miyag, \& Imamura, 2010). 


\section{Conclusion}

Qualitative research is necessarily conducted by a country frequently hit by earthquake. Seismic record of the occurences of the disaster is of importance to analyze the forseeable possibility of impacts that will happen in the future and can also be used as a reference to conceive disaster mitigation measure in the future. Natural disasters that occur in Indonesia exert negative impact apart from damaged area, buildings and the country's interfered economy as they can also be traumatizing to Indonesian. Economic shift can drastically lead to increased stress levels of the society. In this respect, the government is expected to provide assistance not only in the form of material objects, food, but also mental support and scientific information to the victims of the disaster.

The societal life in disaster-prone areas is subject to change. Social values increases as people are getting curious to learn about "how disasters occur, what needs to be prepared ahead before a disaster takes place?", the community felt this as a necessity. Even those who live in areas that are not affected by natural disasters start to learn about it as well.

\section{Suggestion}

From the geographical and geological standpoint, Indonesia is an archipelago with the longest coastline in the world and is a tropical area with many volcanic mountains. The upside is that the fertility becomes the major appeal in Indonesia. Some vital vegetations decrease such as the mangroves in Indonesia which are more effective barriers to take the brunt of the tsunami impact compared to solid structures such as the breakwaters erected. Providing education and government pograms in conserving the mangroves which prove to be effective in dissipating the tsunami impact are of necessity to carry out the mitigation measure in the future.

\section{References}

AHA Centre. (2018). Earthquake In Lombok, Indonesia, (July), 0-8.

BMKG. (2018). Gempabumi Tektonik M=7.7 Kabupaten Donggala, Sulawesi Tengah pada hari Jumat, 28 September 2018, Berpotensi Tsunami.

BNPB. (2014). RENAS-PB-2010-2014.pdf.

Boen, T. (2008). Indonesian earthquake problem. Earthquake, (November), 1-6.

Commission, E. (2018). Mw 6.9 Earthquake in Indonesia, 5 Aug 2018.

Devi, P. R. (2007). A RECONNAISSANCE REPORT ON EARTHQUAKE.

Diambama, A. D., Anggraini, A., Nukman, M., \& Lühr, B. (2018). Velocity Structure of the Earthquake Zone of the M6 . 3 Yogyakarta Earthquake 2006 from a Seismic Tomography Study. Geophysical Journal International, 20, 2156. https://doi.org/10.1093/gji/ggy430

Gaffar, E., Permana, H., Sudrajat, Y., Indarto, S., Bakti, H., \& Nurohman, H. (2018). Geology , Geochemistry and Geophysics of Guci Geothermal Prospect Area, Central Java., (May). https://doi.org/10.3997/2214-4609.201800403

Holloway, R. (1883). Indonesia , Geology, 454-460.

Imamura, F., Muhari, A., Mas, E., Pradono, M. H., Post, J., \& Sugimoto, M. (2012). Tsunami 
disaster mitigation by integrating comprehensive countermeasures in Padang city, Indonesia. Journal of Disaster Research, 7(1), 48-64. https://doi.org/10.20965/jdr.2012.p0048

Kathiresan, K., \& Rajendran, N. (2005). Coastal mangrove forests mitigated tsunami. Estuarine, Coastal and Shelf Science, 65(3), 601-606. https://doi.org/10.1016/j.ecss.2005.06.022

Kongko, W., \& Hidayat, R. (2014). Earthquake-Tsunami in South Jogjakarta Indonesia: Potential, Simulation Models, and Related Mitigation Efforts. IOSR Journal of Applied Geology and Geophysics (IOSR-JAGG), 2(3), 18-22. https://doi.org/10.9790/0990-0231822

Lewerissa, R., Sismanto, S., Setiawan, A., \& Pramumijoyo, S. (2017). The Study of Geological Structures in Suli and Tulehu Geothermal Regions (Ambon, Indonesia) Based on Gravity Gradient Tensor Data Simulation and Analytic Signal. Geosciences, 8(1), 4. https://doi.org/10.3390/geosciences8010004

Lin, M. M., \& Henschke, R. (2018). Gempa, tsunami dan likuifaksi: Rangkaian bencana di Palu yang perlu Anda ketahui - BBC News Indonesia.

Mardiatno, D., Malawani, M. N., Annisa, D. N., \& Wacano, D. (2017). Review on tsunami risk reduction in Indonesia based on coastal and settlement typology. Indonesian Journal of Geography, 49(2), 186-194. https://doi.org/10.22146/ijg.28406

National Agency for Disaster Management (BNPB). (2015). National Disaster Management Plan(Rencana Nasional Penanggulangan Bencana). Retrieved from https://www.bnpb.go.id//uploads/renas/1/BUKU RENAS PB.pdf

Nguyen, N., Griffin, J., Cipta, A., \& Cummins, P. R. (2015). Indonesia's Historical Earthquakes: Modelled examples for improving the national hazard map. https://doi.org/10.11636/Record.2015.023

Nohara, M. (2011). Impact of the Great East Japan Earthquake and tsunami on health, medical care and public health systems in Iwate Prefecture, Japan, 2011. Western Pacific Surveillance and Response Journal: WPSAR, 2(4), 24-30. https://doi.org/10.5365/WPSAR.2011.2.4.002

Nugroho, S. P. (2018). Percepatan Pemulihan Dampak Bencana Terus Diintensifkan di Sulteng Badan Nasional Penanggulangan Bencana.

Pramono, R., \& Harapan, U. P. (2018). Jurnal riset kebencanaan indonesia (BNPB), (August).

Pribadi, S., Afnimar, A., Puspito, N. T., \& Ibrahim, G. (2013). Characteristics of EarthquakeGenerated Tsunamis in Indonesia Based on Source Parameter Analysis. Journal of Mathematical and Fundamental Sciences, 45(2), 189-207. https://doi.org/10.5614/j.math.fund.sci.2013.45.2.8

Putra, R. R., Kiyono, J., Ono, Y., \& Parajuli, H. R. (2012). Seismic Hazard Analysis for Indonesia. Journal of Natural Disaster Science, 33(2), 59-70. https://doi.org/10.2328/jnds.33.59

Ramalanjaona, G. (2011). Impact of 2004 Tsunami in the Islands of Indian Ocean: Lessons Learned. Emergency Medicine International, 2011, 1-3. https://doi.org/10.1155/2011/920813 
Rashid, M; Vetha, Roy D; Chandrasekhar, N. (2010). Science of tsunami hazards. Earthquake, 29(2), 96-126. https://doi.org/10.2307/3973690

Rusydi, M., Efendi, R., Sandra, \& Rahmawati. (2018). Earthquake Hazard Analysis Use Vs30 Data in Palu. Journal of Physics: Conference Series, 979(1). https://doi.org/10.1088/17426596/979/1/012054

Sismanto, S. I. P. and S. (2015). We P3 02 Estimation of Reservoir Permeability from Sismanto $\hat{a} \mathrm{\epsilon}^{\mathrm{TM}} \mathrm{s}$ Equation in 2D Seismic Data of Teapot Dome Field, (June), 1-4. https://doi.org/10.3997/2214-4609.201413078

USGS. (2016). Climate Change Science Activities of the U . S . Geological Survey in New England, (March).

Valkaniotis, S., Ganas, A., Tsironi, V., \& Barberopoulou, A. (2018). A preliminary report on the M7.5 Palu earthquake co-seismic ruptures and landslides using image correlation techniques on optical satellite data, 1-15.

Yanagisawa, H., Koshimura, S., Miyag, T., \& Imamura, F. (2010). Tsunami damage reduction performance of a mangrove forest in Banda Aceh, Indonesia inferred from field data and a numerical model. Journal of Geophysical Research: Oceans, 115(6), 1-11. https://doi.org/10.1029/2009JC005587 